$\underline{\text { Review Paper }}$

\title{
GENETIC AND GENOMIC PROSPECTS FOR CAMEL MEAT PRODUCTION
}

\author{
S. Sabahat ${ }^{1}$, A. Nadeem ${ }^{* 1,2}$ and J. Maryam ${ }^{1}$ \\ ${ }^{1}$ Institute of Biochemistry and Biotechnology, University of Veterinary and Animal Sciences Lahore, Pakistan \\ ${ }^{2}$ Department of Biotechnology, Virtual University of Pakistan \\ ${ }^{*}$ Corresponding Author: asifnadeem@uvas.edu.pk; asif.nadeem@vu.edu.pk
}

\begin{abstract}
Camelids, originating in the Eocene Epoch, have diversified and the modern dromedary occurred during the Holocene in the Arabian Peninsula where it was subsequently domesticated. It provides meat, milk and other products, and Pakistan ranks ninth in the world in terms of camel population. It is well adapted to an arid environment and has a huge potential for food and economic security in the context of climate change, particularly via a genetic improvement for meat production. This article reviews the current knowledge on camel genetics, in relation to genetic improvement. It considers genetic diversity to understand breed differences and their historical origins, using molecular markers, as well as identification of sites of genetic polymorphisms in the camel genome, essential tools for genetic study. Several methods useful for genetic improvement in the camel are considered, including use of candidate genes such as GH, IGF1, GHR likely to affect camel growth. The use of marker assisted selection (MAS) as well as modern methods including genome-wide association studies (GWAS) and genomic selection also been reviewed. Using genetic and other modern technologies, modern farming systems for camels can be introduced making a significant contribution to the rural economy.
\end{abstract}

Key words: dromedary; genetic improvement; genomic markers; camel production. season.

https://doi.org/10.36899/JAPS.2021.3.0253

Published online November 09,2020

\section{INTRODUCTION}

Camel is an important domestic animal in various countries for producing valuable food and for its adaptation to extremely harsh environments (Kadim and Mahgoub, 2008). It can survive in harsh environment with poor vegetation and water; even utilize feed that usually is not consumed by other domestic animals. Due to its multipurpose role, camel is gaining importance as meat producer. During the last decade, research on genetic study to improve camel meat quality has increased and it is vital component to sustain meat consumption. Development in the field of genomics have increased consumer's awareness and motivated camel breeding companies take to more interest on meat quality as well as take account of quality traits as fundamental part of selection programs.

The current paper presents a review on camel diversity, breeds, classification, distribution, domestication, and genetics in general and selection for higher body weights, its subsequent effect on growth performance, production, reproductive traits, meat quality characteristics, carcass traits, growth and effects on genetic parameters. A brief review on genes and genetic polymorphisms associated with body weight and growthrelated traits is also presented.

\section{Current and Future Panoramas for Camel}

\section{History of Camels}

i. Phylogenetic analysis: Camel ancestors were found in North America back to Eocene epoch (around 40 million year ago) (Burger, 2016). After separating into New World and OldWorld camels, the latter migrated to the Eastern Hemisphere by the Bering land bridge. The earliest Asian camel can be traced back to 5 million years ago (Mya) (Kozhamkulova, 1986). One-humped and twohumped camel divergence was estimated to occur between 5 and 8 Mya (Wu et al., 2014), and wild and Bactrian camel diverged between 0.7 and $1.5 \mathrm{Mya}$ in the Pleistocene before domestication (4000-6000 ya).

ii. Classification of Camelidae: The taxonomic classification of camels is Class Mammalia, Order Artiodactyla (even-toed ungulates), Suborder Tylopoda (animals with padded feet), and Family Camelidae. Old world Camelids (Camelini) and New World Camelids (Lamini) are two subfamilies of Camelidae. Genus Camelus is comprised of two species, one humped and two humped camels. Camelus dromedarius (one humped camel) is mainly distributed in the warm arid region of the Middle East and Africa while Camelus bactrians (two-humped camel) is distributed in China and central Asia. It is also found in Mongolia and China where it is known as Camelus bactriansferus. 
iii. Domestication: Old world ancient civilizations and numerous rural and roaming societies of Asia and Africa depended on camel for milk, meat, transportation and wool production. The dromedary, Camelus dromedarius ranges from East and North Africa to Pakistan and was also introduced into Australia for inland transport in the early $19^{\text {th }}$ century. Global structure of East African and south Arabian dromedary was differentiated at nuclear level from North Arabian, North African and South Asian individuals (Almathen, 2014; Charruau, 2012; Schulz et al., 2010) During the Holocene epoch, presence of bones of wild dromedary indicates their presence on Arabian Peninsula along hunting site of eastern coast (Von den Driesch and Obermaier 2007). A zooarchaeological study also revealed that domestication took place in the coastal southeast Arabian Peninsula (Grigson, 2012; Grigson, 2014; Uerpmann and Uerpmann, 2002; Uerpmann and Uerpmann, 2012). A genetic study of recent and ancient DNA confirms this region as the possible place of domestication.

Current camel and world-wide breed distribution: The world camel population is estimated to be about 28 million (FAOSTAT, 2017), out of which $85 \%$ are distributed in Africa and 15\% in Asia. Out of that, $70 \%$ of the African population is found in Somalia and Sudan while Kenya, Ethiopia and Chad contain $15 \%$ of camels in Africa. Pakistan ranks about the ninth as a major camel rearing country in the world after Somalia, Sudan, Ethiopia, Niger, Mauritania, Chad, Kenya and Mali. Since 1961, the world camel population was more than doubled with a yearly growth rate of $3.4 \%$ (Faye, 2015). There are about 50 camel breeds in the world, out of which 27 breeds are present in North, West and East Africa, Arabic countries and Pakistan. These are as Gabbra, Nord, Deshi, Ait, Steppe, Chumbi, Khawar, Manga, Somalie, Azmiyah, Dera Ismail Khan, Adrar, Sidi, Mekrani, Khiva Turkana, Cheikh, Mowallad, Tibesi, Ouled Targui, Arab, Soudani, Ajjer, Berabiche, Khebbach and Benodir. West and North Africa, India, and the Arabian Peninsula contain 20 breeds, namely Gandiol, Azaouak, Bekaneri, Umaniyah, Guban, Indi, Mudugh, Turkana, Sahel, Rashaidi, Pellahi, Fleuve, Bekaneri, Reguibi, Riverine, Urfilla, Grain, Donkali, and Arabi. Bishari, Air and Anafi camel breeds are found in Africa and Sudan (Blanc and Ennesser 1989; Sakandar et al., 2018).

Camel distribution in Pakistan: The dromedary, Camelus dromedarius, is the most widely distributed and numerous camel species in Pakistan and is found in hot and arid regions of the country whereas the smaller population of the Bactrian camel, Camelus bactrians, is found in the northern areas. The camel population is about 1 million in Pakistan (Government of Pakistan, 2017). The distribution of the dromedary varies across the country. Baluchistan has the highest population (41\%) followed by Sindh (30\%), Punjab (22\%) and KPK (7\%). Pakistan has four ecological zones of camel distribution according to Qureshi et al., (1993), namely 1) coastal mangroves (Badin, Thatta and Karachi district of Sindh); 2) sandy deserts (Cholistan and Thal in Punjab and Thar in Sindh); 3) mountainous tracts of Baluchistan, D.I. Khan and D.G. Khan districts of KPK and Punjab, respectively); and 4) irrigated plains of Punjab and Sindh.

Camel breeds in Pakistan: Twenty breeds of camel have been documented by Isani and Baloch (2000) in Pakistan, seven breeds in Baluchistan, four in KPK four in Sindh and five in Punjab. Pakistani camels are Kachhi (Jacobabad andSibi region), Brahvi(Chagi district and Sindh region region), Makrani (Makran, Lasbela, Kharan, Dadu and Karachi region), Gaddi (Lucky Marwat Waziristan Agency and D.I. Khan region), Bagri (Cholistan and Thal deserts region), Lassi (Lasbela, Balochistan and Sindh region), Rodbari (Makran, Pasni, Turbat and Khuzdar region), Ghulmani (Dera Ismail Khan, D.G. Khan and Zhobe region), Maya (KPK Tribal areas region), Kala-chitta (Pabbi, Sohawa and Salt Range region), Khader (NWFP, extend between Sulaiman Range and Indus River region), Marecha (Cholistan, Thal and D.I. Khan region), Brela (Jhang, Muzaffargarh, Multan, Mianwali includes Thal area region), Kharai (Chohar, Kharo Chhan and Jamali, Thatta, Badin and coastal areas of Karachi and Kacchregion), Larry (Hyderabad and Badin region), Dhatti (thari) (Tharparkar, Umerkot and Mirpurkhas. Sanghar and Badin region), Sakrai (Mirpur Sakro to SujawalTallukas of Thatta district region), Cambelpure (Attock, Rawalpindi, Chakwal Jehlum Mianwali and Sargodha region), Kharani (Kharan, Jhalawan and Bordering Kala region) and Pishin from Pishin and Quetta region.

Camel population trends in Pakistan: For 18 years (1990-2007), a mixed trend of positive and negative population growth was observed. The camel population was 1 million during 1990-1994 and declined to 0.8 million in 1995 and a further decline in population to 0.7 million in the next two years, i.e. a decline of $29 \%$ between 1994 and 2004. In 2007-08, camel population again increased to one million (Government of Pakistan, 2008). The camel population remained stable since the last decade and is now 1.2 million (Government of Pakistan, 2017).

\section{Current and Future Prospects for Camel Production}

Economic importance of the camel: According to Iqbal (1999) and Raziq (2009), the camel has great economic importance in the developing world as it provides an inexpensive source of power in ploughing, drawing water from wells and land levelling. On Eid ul Ezha, the camel is slaughtered blissfully by Muslims and gains a good price at this event. Pakistan exports camels to Egypt, Saudi Arabia, Libya, the Gulf and other Arab countries. 
The camel industry flourishing in Arab states due to camel racing. In Sudan, a racing camel can have a price up to 15 million dirhams (Rs 550 million). An ordinary camel in a market can fetch 2-3 thousand Dhs/male (Rs 70-110 thousand) and 4-6 thousand Dhs/female (Rs 150200 thousand) (Manefield and Tinson, 1997).

Due to global warming, the camel is gaining importance as the most favourable animal to be developed genetically, due to its climatic adaptability. Annually, 0.24-million -ton of milk and 50-thousand-ton of meat form the camel is produced in Pakistan which valued at Rs 2.4 billion and Rs 250 million respectively (Government of Pakistan, 2008). Camel hides are used to manufactures beautiful decorative articles, sandals and saddles which are exported. Twenty-thousand tons of camel hair are used for manufacturing blankets, tent cloth, ropes and floors mat annually. Soft woolly fleece of new born calves is mixed with hairs and used for manufacturing blanks (Khan et al., 2003) These suggest that by improving conventional management system with modern farming practices, the life of nomads can be improved whose lives depend on raising camels.

General characteristics of camel meat: The chemical composition and nutritional value of camel meat distinguish it from beef and mutton. Camel meat is considered best at the age of 4-5 years. Due to the presence of glycogen, it has a slightly sweet taste and its colour varies from red to dark brown. On the basis of its low fat and high moisture contents, it can be distinguishing from beef and mutton. Camel meat is rich in proteins and minerals including Vitamin $\mathrm{E}$ has a high water-holding capacity compared with beef (Soltanizadeh et al., 2010). Camel meat is an excellent source of vitamins especially vitamin B complex and various minerals such as calcium, iron and phosphorous. It is considered a healthy food for humans due to the low level of cholesterol (75-86 mg/100 g) and high amino acid contents compared to other animals.

Camel meat as medicine: Camel meat is also used in medical purposes to reduce risk of diseases such as hypertension, hyperacidity, pneumonia and respiratory diseases (Kurtu, 2004). Camel meat has been used as traditional medicine for the last sixteen centuries in China. It is used to improve resistant against diseases and is helpful to give strength of muscles and bones, to reduce pain and give moisture to skin. Camel hump fat is used efficiently to relieve pain and swelling (Qiu et al.,2002). Due to presence of linoleic unsaturated fatty acid, it has ability to protect from cancerous tumour reported by some researchers. Studies have proved that camel meat can be useful in treatment of cancer, infections, stork, and sciatica (Abrhaley and Leta, 2018). Camel meat has high unsaturated fatty acid content as compared to beef and due to its unique features (Soltanizadeh et al., 2010).
Potential of meat production in camel: As a meat producer and due to its adaptability, the camel is becoming a more significant livestock species. Camel meat is typically produced by old conventional production system and its meat is mostly obtained from old animals that became less valuable and unable to provide milk, transportation and breeding (Tandon et al., 1988). Under these conditions, camel meat is considered coarse, tough, watery and sweet in flavour as compared to other meat sources.

There is evidence to show high demand for fresh camel meat when it is used for blended products, however, the marketing system of camel meat is not well organised (Pérez et al., 2000). To fulfil the growing demand of developing countries, camel meat provides a good and cheap option to accomplish their meat requirements (Saparov and Annageldiyev, 2005). However, as camels are raised primarily in underdeveloped countries, limited research work has been done to improve their reproductive and productive characteristics.

Camel growth rate: The dromedary camel is one of the most important domestic animals in the arid and semiarid regions as it is equipped to produce high quality food at comparatively low costs under extremely harsh environments. The camel has great tolerance to high temperatures, high solar radiation and water scarcity. Tandon et al, (1988) noted that the camel is likely to produce animal protein at a comparatively low cost in the arid zones based on feeds and fodder that are generally not utilized by other domestic species due to either their size or food habits. The average birth weight of the dromedary camels is about $35 \mathrm{~kg}$, but it varies widely between regions, breeds and within the same breed. Reports on camel birth weights range between $27 \mathrm{~kg}$ and $39 \mathrm{~kg}$, which is comparable with that of tropical cattle breeds (Bakheit et al., 2012). Hammadi et al., (2001) reported camel body weights of $27,48,65$, and $79 \mathrm{~kg}$ at birth, 30, 60 and 90 days of age, respectively, which indicates a daily growth rate of $580 \mathrm{~g}$ /day between birth and 90 days of age. The limited work carried out on improving camel nutrition demonstrated significant relationships between daily gain and daily intake of concentrates for dromedary camels. (Kamoun, 1995).

\section{Genetics of Camel}

Genetic improvement of camel meat: With the potential role of contributing to food security, as well as consumer interest and acceptance of camel meat, there is a need to increase meat production, and this may in part be achieved by genetic improvement of camel meat quality and quantity. Meat quality can be improved genetically by applying molecular marker technology which in part removes the need for extensive phenotyping. Proteomics and functional genomics are 
very helpful tools for understanding function and regulation of genes related with specific trait. Gene expression, DNA sequencing, protein analysis, microarray analysis are advanced techniques that can be used for genetic improvement of meat. Thus, by using molecular marker technologies, meat quality can be improved (Gao et al.,2007).

Genetic diversity: Genetic diversity between individuals of Camelidae family such as the Bactrian camel (Chuluunbat et al., 2014; Jianlin et al.,2004), dromedary breed (Mburu et al..2003), llama, guanacos and alpacas (Kadwell et al,. 2001) were analysed by using molecular markers. Phylogenetic analysis was performed for determination of evolutionary lineage of llama and alpaca. (Kadwell et al., 2001; Stanley et al., 1994). Two closely related species of Mongolian domestic and wild Bactrian camels show $2.9 \%$ genetic diversity in the mitochondrial region. Genetic studies in camels have verified that there is high sequence variation at both mitochondrial (Ji et al., 2009; Silbermayr et al., 2010) and nuclear loci (Shah et al., 2006; Wang et al., 2012). Dromedary and Bactrian camels have undergone full genome sequencing and analysis. Scientists from Saudi Arabia, and China sequenced 2.2 billion nucleotides in the camel's genome (Mahmoud, 2010).

Molecular markers have been successfully amplified in camelids to study genetic distance between Mongolian and Chinese domestic Bactrian camels (Charruau, 2012; Jianlin et al., 2004). Babar et al. (2015) studied genetic diversity in Barela and Marecha camel breeds of Pakistan. Cyto-b gene and D-loop analysis indicated low genetic diversity in these two breeds. The phylogenetic analysis indicates dromedary and Bactrian camel as two different clades that originated from divergent lineage and have distinctive genetic distance.

Genetic diversity and association among Kenyan, Pakistan, Saudi Arabia and United Arab Emirates dromedary camels were studied by using microsatellite loci. Phylogenetic analysis showed that Kenyan dromedaries are distinctive from Pakistani and Arabian population (Vijh et al., 2007). Almathen (2014) reported on the geographic distribution of genetic diversity in dromedary camels from 21 countries, demonstrating the wide range of this breed. Microsatellite markers and mitochondrial DNA were used for analysis.

Effective population size: The effective population size $\left(N_{\mathrm{e}}\right)$ is one of the most important parameters in conservation and evolutionary processes, as a reduction in $N_{\mathrm{e}}$ may cause a loss of genetic variation, increase in frequency of lethal mutations, and a decline in the ability to adopt to natural and human-induced environment change. Reduction of actual population size and $N_{\mathrm{e}}$ threatens population viability due to modification, exploitation, habitat loss and altered population dynamics (Allendorf and Luikart, 2007). While it is very difficult to estimate $N_{\mathrm{e}}$ directly because it is hard to measure all the demographic factors that influence this parameter in wild populations (Frankham, 2005), using genetic data has become a popular and convenient method to estimate $N_{\mathrm{e}}$. Various methods are available (Ovenden et al., 2007; Schwartz et al.,1998) that help to estimates $N_{\mathrm{e}}$ such as gametic disequilibrium (England et al.,2006; Hill, 1981; Waples, 2006), and linkage disequilibrium (LD) (Tallmon et al., 2008; Wang et al., 2012). Population structure was studied by using mitochondrial and nuclear microsatellites in Mongolian Bactrian camels. The clustering results reported that $97 \%$ of nuclear and $73 \%$ of mitochondrial variation occurred within populations, it between. These results show low population differentiation and high levels of gene flow among Mongolian camel breeds (Chuluunbat et al.,2014).

Linkage disequilibrium: The term 'linkage disequilibrium' (LD) was first used by Lewontin and Kojima,(1960) and simply used to indicate non-random association of alleles at different loci. LD has gained importance in human genetics, agricultural genetics and evolutionary genetics as it provides information about past history of a species and it constrains the potential response to both natural and artificial selection. The pattern of LD reflects the breeding system, geographic distribution, and population history throughout the genome but in each genomic region it reflects gene conversion, natural selection, mutation and rate of evolutionary change. Nowadays, LD is mainly considered in relation to SNPs that are diallelic and mutate in very low rates (Slatkin, 2008).

Genetic polymorphisms: A genetic polymorphism is the existence of more than two alternative forms of DNA sequence that are genetically distinctive and structurally different. These mutations range from change of a single nucleotide to hundred bases. A SNP is the simplest form of polymorphism that can be situated in the regulatory region of the genes or whole genome. These polymorphisms are significant for their use to differentiate DNA markers and have many applications in the field of molecular genetics for Genetic testing, Gene mapping, Detection of heterozygous disease in livestock, Paternity testing, DNA fingerprinting, Donor-recipient matching for tissue and organ transfer and Determination of genetic relationships among different strains, breeds and breeding lines of livestock(Yahyaoui et al., 2001). Various types of molecular markers are now used for specific traits in livestock animals.

\section{Candidate Genes for Improving Growth in Camels}

1. Growth hormone: Growth hormone (GH), also known as somatotropin, is a polypeptide hormone produced and secreted by somatotropic cells of anterior pituitary gland. It plays an important role in development and growth of mammals (Butler and Roith, 2001). 
i. Biological function of GH: GH has diverse effects and its receptor is expressed in various tissues. GH function is stimulated by binding with GHR on the cell membrane of specific tissues. These receptors activate tyrosine kinase, particularly JAK2. Binding of JAK2 with receptors causes phosphorylation of kinase and activators of transcriptional family, particularly STAT5 which activate gene expression and causes production of IGF-1 (Argetsinger et al., 1993).

ii. Organization of the growth hormone gene: The GH sequence of Camelus dromedarius was studied by Maniou et al., (2004). The length of camel GH is about $1900 \mathrm{bp}$ and consists of five exons (lengths 71, 161, 17, 162 and 200 base pairs) and four introns (Maniou et al., 2001). The location in the camel genome is not known. However, it is located on Chromosome 19 atq26 in cattle (Hediger et al.,1990), and in buffalo; it is located on Chromosomal 19 from base pair 157215-159046.

iii. Polymorphism associated with the growth hormone gene: GH plays important role in selection of growth trait in livestock's and serve as candidate gene (Daverio et al., 2012). Thomas et al., (2007) reported an association of polymorphism in GH with growth and carcass trait in Brangus bulls. In addition, an association between body weight and secretory function related with GH polymorphism in Japanese black calves (Katoh et al., 2008). Body measurement relationships of SNPs with GH gene was studied in six Sudanese breeds by Ishag et al. (2010).

Afifi et al., (2014) studied polymorphism association between the growth hormone gene and body weight gain in the camel. The association was studied in four Saudi Arabian camel breeds, viz. Majaheem, Saheli, Waddah and Homor breed. SNP T450C was found to be linked with body weight gain. Saheli camels had a heavier body weigh with CC genotype than CT and TT genotypes. This study verified that this SNP can be used as a marker for selection of higher rate of growth and meat production in camels. Abdel-Aziem et al., (2015) studied genetic polymorphism of GH gene in Somali, Sudany, Maghrabi, Mowaled and Falahy camel breeds in Egypt. Maghrabi camel that is used as dual-purpose camel shows a higher frequency for allele $C(0.75)$ than other four breeds. These findings provide credibility to the hypothesis that $\mathrm{GH}$ is an ideal candidate gene for growth-associated traits in livestock.

iv. GH and IGF-1: There is an important association between GH and IGF genes to do with controlling growth and metabolism during foetal and postnatal development (Mertani and Morel, 1995). The GH-IGF axis consists of GH, GHR, the GH binding proteins (GHBP), IGF-I, IGFII, IGF receptors and the six IGF binding proteins (IGFBP Both GH and IGF-I have a significant effect on the growth and physiology of an organism (Schuller et al.,1993).

v. GH-IGF in cell proliferation and apoptosis: GHR mRNA and protein was identified in bovine mammary gland tissue, (Plaut et al., 2003; Sinowatz et al, 2002; Zhou, 2007). GH stimulates proliferation in epithelial cells (Knight et al., 1990). During regulation of the cell cycle, IGF-1 can stimulate proliferation of cells (Evan and Vousden, 2001).

vi. GH and IGF-I in body regulation and muscle development: $\mathrm{GH}$ plays a key role in growth, development, lactation and reproduction. Laron's syndrome in humans is caused by deficiency of GH, and that can affect growth during infancy and result in adolescence of short stature (Etherton and Bauman, 1998). Excess of GH causes gigantism that results in a condition called acromegaly that results in enlargement of bony tissue, carpal tunnel syndrome, hypertension headaches, cardiomyopathies and diabetes mellitus. The effect of GH is chiefly moderated by IGF-1 (Ayuk and Sheppard, 2006).

vii. GH-IGF in transport processes: $\mathrm{GH}$ affects amino acid transport and protein synthesis in various tissues. Transportation and utilization of amino acid in perfused rat liver can be simulated by GH. Concentration of seven amino acids such as serine, alanine, lysine proline, glycine threonine and arginine increase in media that contain GH (Jefferson et al., 1975). IGF can stimulate protein synthesis and enhance cellular uptake of amino acid (Dimitriadis et al., 1992, Nielsen and Jakobsen, 1993; Louveau and Gondret, 2004).

viii. GH and GHR: GH is polypeptide hormone which is produced and secreted by acidophilic cells of the pituitary gland (Wood et al., 1989). Binding of GH with two GHR induces signal transduction (Sundstrom et al., 1996). GHR consists of a single transmembrane domain, an extracellular domain and cytoplasmic domain (Gordon et al., 1983). Sabahat et al. (2020) characterized the genetic variability and reported the amino acid substitutions in growth hormone and growth hormone receptor genes mutants in Camelus dromedarius.

2. IGF-1: IGF-1 is a polypeptide hormone which belongs to the family of growth factors, and plays a key role in regulation of growth, differentiation and development (Martin and Stoica, 2002). IGF-1 is mainly produced by the liver as an endocrine hormone (Combes et al., 1997). IGF-1 can also be synthesized by various tissues and has the ability to stimulate cell growth by paracrine and autocrine fashion (Yee, 1994). IGF-1 production is stimulated by $\mathrm{GH}$ and is affected by nutrition. IGF-1 plays a significant role in juvenile and adult growth by binding with specific receptors of various tissues. IGF-1 
acts in three different ways by the endocrine system (Butler and Roith, 2001).

i. Organization of the IGF-1 gene: The location of IGF1 gene in Camelus dromedarius is unknown. IGF-1 is present on chromosome 5 in cattle (Miller et al., 1991). IGF-1 plays a vital role in growth, embryogenesis, cell discrimination and regulation of metabolism. It is formed by arrangement of 70 amino acid and has a molecular weight of $7.5 \mathrm{kDa}$. (Dimitriadis et al., 1992). Humans, cattle, dogs and pigs have an identical amino acid sequence (Rinderknecht and Humbel, 1978). Exon numbers vary between different species, for example pigs, goat and sheep have six exons while human, rats and camels have five (Rotwein, 2017).

ii. Polymorphism associated with IGF-1 gene: IGF-1 considered as effective candidate marker for growth and meat production in livestock. A high IGF-1 concentration was reported in the blood of Simmental which is beef breed, compared with dairy Holstein cows. However, growth rate shows an association with concentration of IGF-1 in both breeds (Schlee et al., 1994). The association between growth rate and high level of IGF-1 also reported by Barash et al., (1998). However, a negative correlation was also observed between growth rate and level of IGF-1 in Angus cattle by Ge et al., 2003). Siadkowska et al. (2006) reported an association of polymorphism of IGF-1 gene with meat production traits in Holstein Friesian cattle. Three SNPs were reported in IGF-1 gene by Fatima et al. (2009) in three buffalo breeds of Gujrat.

Sixteen SNPs were identified in IGF-1 and GH genes of Holstein Friesian dairy cows and found to be associated with milk production, growth rate and fertility traits (Mullen et al. 2011). Kim et al., (2005) reported a novel SNP in the IGFBP-3 gene of Korean cattle. Choudhary et al., (2007) studied polymorphisms of IGFBP-3 gene associated with body weight and birth weight in Holstein Friesian and crossbred cattle. Different breeds have variable concentrations of IGF1 in plasma (Rhoads et al,. 2008). Ozawa et al., (1995) found different concentration of IGF-1 in heavy horses, light horses and ponies. IGF-1 concentration in serum has been reported in different breeds of horses including Thoroughbreds (Noble et al., 2007) Standardbred trotters (Champion et al., 2002), and Quarter horse (Ropp et al. 2003). Genetic polymorphisms in insulin-like growth factor-1 (IGF-1) gene of Pakistani Marecha camel breed were reported by Sabahat et al. (2020a). A significant finding was the occurrence of a $\mathrm{T} \rightarrow \mathrm{C}$ polymorphism in exon 5 that causes a substitution of an amino acid from Cysteine to Arginine.

In Nellore, Canchim and various other cattle breeds, significant associations between body weight and SNPs have been reported by Curi et al., (2005). A study evaluated SNPs in the promoter region (C-512T) of IGF-
1 and SNPs found between exon 3 and 4 showed a positive association with growth traits in Angus cattle (Ge et al., 2001). A SNP in the promoter region of IGF-1 (IGF1/SnaBI) in Charolias cattle breed has been found to be associated with growth trait and can be helpful for genetic evaluation of this breed with MAS strategies (De la Rosa Reyna et al., 2010).

3. GHR: The growth hormone receptor (GHR) is a transmembrane protein and is considered a very important candidate for growth, meat and milk traits in livestock. The binding ability of GH on target tissues is affected by changing function of GHR (Di Stasio et al., 2003). Mutation of GHR gene causes Laron syndrome and idiopathic short stature in humans (Blair and Savage, 2002; Tixier-Boichard, 2002).

i. Organization of the GHR gene: The location of GHR is unknown in the camel. GHR gene is located from base pair 2960112-3196609 and about 236498bp. GHR comprise of 10 exons.

ii. Polymorphism associated with the GHR gene: Dybus and Grzesiak (2006) and Kmiec et al. (2007) reported several polymorphisms in bovine GHR. Growth hormone exerts its effect on growth and metabolism by interaction with GHRs that are present on the surface of target cells (Hradecka et al., 2008). GHR can alter activity of $\mathrm{GH}$ by changing its functional region and signalling pathway. Rahbar et al., (2010) reported SNPs in the promoter region of GHR and found a significant correlation with milk trait in Holstein cows. Five polymorphisms have also been documented in East Anatolian red cattle, Turkish grey cattle and South Anatolian red cattle (Akad et al., 2012). Andreas et al., (2010) studied genetic polymorphism of GH and GHR genes in buffalo to evaluate them as candidate genes in meat production

$\mathrm{GH}$ is major regulator of metabolism and growth and influences health, growth, aging and milk production by modulating the expression of IGF-1 (Lincoln et al., 1995; Sumantran et al.,1992) and it was also verified that GHR mediates the function of GH on specific cells by signal transduction across the cell membrane and transcription of various genes including IGF-1 (Argetsinger and Carter-Su, 1996; Rotwein et al,. 1994). Thus, GH and GHR genes are key candidate genes for the detection of genetic markers for growth, carcass, meat and milk traits in livestock (Ge et al., 2003).

\section{Additional Genetic Considerations}

Mapping loci for meat quality: Meat quality is affected by number of quantitative trait loci (QTL) and various other factors. Genomic technologies are now used for mapping loci that affect meat quality (Koopaei and Koshkoiyeh, 2011). In association analysis, candidate genes and linkage mapping markers are used to detect 
QTL. Bioinformatic and genomic analysis are useful to differentiate genes on the basis of their function in livestock species including camel. Marker-assisted selection (MAS) by using information from meat (QTL) loci, can be useful in a breeding selection program. These technologies play an important role in genome mining and gene discovery. However, RAPD, SNP, RFLP, microsatellite, SSLP, VNTR are various techniques that are being used in the last decade. Biological researchers are taking great interest in modern technologies such as microarrays, high density SNP (HD-SNP) arrays to study genetics and genomics of animals (Fan et al., 2010). Genetic variation information within and across breeds can be obtained by using these techniques.

Genes associated with meat quality traits: The three candidate genes described earlier, GH, IGF-1 and GHR, are relevant to meat production, given their role in overall animal growth. However, there are some additional candidate genes to consider that are specific to meat quality traits. The myogenic factors (MYF) 5 and 6 considered essential for initiation and development of skeletal muscles and phenotypes maintenance in camel (Shah et al., 2006). FABP4 plays a major role in the regulation of glucose and lipid homeostasis. FABP4 gene polymorphism shows associations with economically important traits such as fat and marbling in cattle (Michal et al., 2006).

Leptin (LEP) also plays an important role in energy metabolism, food intake, body weight and energy expenditure (Woods et al., 1998), immune system (Lord et al., 1998) and reproduction (Garcia et al., 2002). Significant associations of LEP polymorphism with feed intake (Oprządek and Flisikowski, 2003), body fatness (Buchanan et al,. 2002) and marbling scores (Nkrumah et al., 2004) and milk yield (Buchanan et al,. 2003) have been detected. Thyroglobulin (TG) is the precursor of thyroid hormones which plays an important role in lipid metabolic regulation and, other functions (Barendse et al., 2001).

Making use of genetic markers for meat quality trait genes: Having identified genes associated with meat quality traits, the next issue is how to best utilize this information. Gene markers are advanced and powerful technology which will be helpful livestock breeders to attain their breeding target specifications. Gene markers are becoming available for a variety of performance, conformational and disease traits.

However, the markers need evaluation, and it is now necessary for breeders to utilize best gene marker technology (Davoli and Braglia, 2007). Three options are available to breeders to make optimal use of this technology. Firstly, breeders may simply buy sires that have been bred utilizing information on useful gene markers. Secondly, breeders can evaluate gene markers in their own herd to set up breeding stock with the most advantageous gene marker profiles for further use. Thirdly, breeders can buy sires with distinct gene markers and carry on breeding inside their herd to achieve an improvement in their livestock profiles (Meuwissen et al., 2013).

Marker assisted selection: Marker assisted selection (MAS) uses quantitative trait loci (QTL) information for livestock selection programs (Davis and DeNise, 1998). The first requirement in the selection of molecular markers is the identification of candidate's genes related to the economically important trait. Candidates genes have potential a relationship with physiological and biochemical processes and allow the detection of single nucleotide polymorphism (SNPs) in the gene that are the basis for variation in a trait.

MAS has the ability to increase the genetic gain rate in animals where conventional phenotypic selection is less efficient (Abdel-Azim and Freeman ,2002). MAS could be useful in genetic gain, reduction in generation interval and expanding selection differentials. These goals can be attained by using MAS through selection of young bulls before progeny testing (Mackinnon and Georges 1998). Sabahat et al. (2020b) investigate patterns of variation in birth weight and weaning weight of Marecha and Lassi camels breed of Pakistan and developed spline-based growth models.

Meat quality enhanced by MAS: In the past, traditional phenotype-based selection shows a slow rate of genetic improvement with low accuracy but in modern farming animal systems, DNA-based technologies and genetic markers have changed the breeding abilities for livestock. Specific DNA variation associated with meat quality characteristic can be identified by QTL mapping and selective improvement undertaken by MAS. In farm animals, undesirable characteristics in the population can also be eliminated by using MAS. DNA markers related to softness and marbling of beef is commercially available, for instance GeneSTAR ${ }^{\mathrm{TM}}$ Tenderness; these SNP markers are used to test for meat tenderness (Allais et al., 2014). Page et al., (2004) utilized GeneSeek Company's MassArray SNP chip and identified two SNPs associated with meat tenderness in the Calpain 1 (CAPN1) gene.

However, there are some limitation of QTL mapping as it is difficult to find and prove a causative mutation associated with a QTL (Andersson, 2001). The main hurdle is to localize QTL, as fine-mapping can be a daunting task. Along with QTL mapping, various approaches such as genomics, proteomics and metabolomics are needed to understand the genetic architecture of complex traits (Liu and Cheng, 2002).

Influence of breed on meat quality: Breed can influence meat quality in different ways such as meat physiology and muscle structure (Sañudo et al., 2004; 
Waritthitham et al., 2010). In cattle, it has been reported that native breeds have benefits such as high reproductive rate, crude feed tolerance, low maintenance, dressing percentage and growth rate are low (Liu et al., 2006; Shengli, 2009; Xie et al., 2012). Similar benefits may flow in to selecting appropriate breeds of camel for their environment. Cross-breeding may also be important, particularly if done using a marker-assisted introgression approach, binging desirable alleles over from one breed into another (Charcosset, 1997).

Application of genome-wide association study: While candidate genes are one approach to selecting useful genes for MAS, a genome-wide association study (GWAS) can identity a large number of potentially useful markers. GWAS is a modern technique for detection of genes associated with traits of interest, used in humans, as well as agricultural species including domestic animals. GWAS mainly uses SNPs linked with sequence variations of the genome along with pedigree and phenotype information to discover associations to recognize genes that play a key role for the trait of interest. It was first used in human disease analysis and made great progress (Hirschhorn and Daly, 2005). GWAS was expanded to the breeding and genetics of domestic animals when genomic sequences of various domestic animals were available, and the number of SNPs on a SNP chip increased as a result of sequencing and re-sequencing. There are various types of SNP chip commercially available for cattle $(50,000$ SNPs; Illumina BovineSNP50 BeadChip), sheep (56,000 SNPs), chickens $\quad(60,000 \quad$ SNPs; Illumina ChickenSNP60 BeadChip). horses (54,602 SNPs; Illumina EquineSNP50 BeadChip), dogs (22,362 SNPs; Illumina CanineSNP20 BeadChip) and pigs $(60,000$ SNPs; Illumina PorcineSNP60 BeadChip) (Wang et al., 2012).

GWAS related to meat quality of cattle has been studied and reported by Bolormaa et al. (2014). A GWAS was carried by Sorbolini et al. (2015) to find out significant association of markers with carcass and meat traits in the Marchigiana breed of cattle. Sherman et al. (2009) studied associations between feed intake and markers and found associations of 161 SNPs with net feed intake. Growth, meat quality and carcass traits were measured on 490 bulls and genotyped by using the Illumina 50K Chip.

Marecha and Lassi are two important breeds of camel, and GWAS of these breeds with meat quality and growth trait will most likely result in improved camel meat production and helpful to fulfil requirement of meat industry in Pakistan.

Genomic selection and progress of livestock: In the early stages of QTL mapping, low-density microsatellite markers where used, and by the 2000s, more than 15,000 SNP markers have been developed on the one SNP chip (Khatkar et al., 2008). Today, SNP chips of more than
$50,000 \mathrm{SNPs}$ are available for association studies. It is now possible to select animals by using these SNPs markers simultaneously. Genomic selection was first of all proposed by Meuwissen et al. (2001). Many livestock companies are now planning for implementation of genomic selection in breeding and management programs. Application of genomics approach has moved quantitative genetics to molecular genetics and will move genetical genomics to system genetics (Kadarmideen et al., 2006). Genetic progress of livestock can be enhanced by using different practical ways, among which three are most beneficial, namely, (1) precision of selection (2) reduce generation interval and (3) enhance selection intensity. Whole genome selection is one of the effective tools that influence genetic progress as accuracy can be increased and generation interval can be reduced. Along with phenotypic and pedigree information, this approach becomes most powerful and practical for creating breed improvement though changes in DNA.

Application of functional genomics to improve camel meat quality: New opportunities have been created by recent technologies to study complex characteristics of meat quality traits in the camel. Instead of investigating the association of a single gene or DNA marker with a specific trait such as meat quality, researchers are now focusing their interest to reveal gene expression profiles, gene clusters and association that are characteristics of a specific phenotype.

With the improvement of advanced techniques such as proteomics and DNA arrays, DNA microarray and proteomics help in the study of regulatory events that control biological functions by gene expression profiling. For example, gene and protein expression in muscles has been studied in the MUGENE program (Hocquette et al., 2010) in which young Charolais bulls and steers were studied. During this study, new molecular tools such as DNA chips and dot blot quantitative tools were used for analysis of muscle and beef quality (Guillemin et al., 2011). These genomics technologies are now used in meat production sectors (Mullen et al,. 2006). Advanced technologies can be applied in livestock species for improvement of productivity, heath and genetic selection of animal by an integrated use of a range of molecular 'omics' tools (Suravajhala et al., 2016).

Modern Interventions to Improve Camel Production: Based on the natural resources and herd mobility, conventional camel farming systems are widespread in the world. Productivity of the camel is very low due to very sluggish reproductive cycle, elongated gestation period (13 months), delayed precocity for reproduction (not earlier than 3 years), extended calving interval (usually 2 years) and high mortality rate. The conventional farming system of camels shows high unpredictability in production and it requires improvement to meet increasing demands for products 
(Marai et al., 2009). This potential could be achieved by modernizing camel productivity through intensified systems. Modernized camel farming systems show evidence of improved milk and meat production as compared to traditional farming system. As indicated in the previous sections, application of genetics, and increasingly genomics, has the potential to increase camel productivity in Pakistan.

\section{REFERENCES}

Abdel-Aziem, S., H. Abdel-Kader, S.S. Alam and O.E. Othman (2015). Detection of MspI polymorphism and the single nucleotide polymorphism (SNP) of GH gene in camel breeds reared in Egypt. Afr. J. Biotechnol. 14(9): 752-757.

Abdel-Azim, G. and A. Freeman (2002). Superiority of QTL-assisted selection in dairy cattle breeding schemes. J. Diary Sci. 85(7): 1869-1880.

Abrhaley, A. and S. Leta (2018). Medicinal value of camel milk and meat. J. Appl. Anim. Res. 46(1): $552-558$.

Afifi, M., E.M. Metwali and P.H. Brooks (2014). Association between Growth Hormone Single nucleotide polymorphism and body weight in four Saudi camel (Camelus dromedarius) breeds. Pakistan Vet. J. 34(4).

Akad, I.A., A. Mengi and K.Ö. Öztabak (2012). A determination of growth hormone receptor gene polymorphisms in East Anatolian Red cattle, South Anatolian Red cattle, and Turkish Grey cattle. Turk. J. Vet. Anim. Sci. 36(1): 27-33.

Allais, S., C. Hennequet-Antier, C. Berr, M. Chabault, F. d'Abbadie, O. Demeure and E. Bihan-Duval (2014). Fine mapping of QTL for carcass and meat quality traits in a chicken slow-growing line. In: Proceedings of the $10^{\text {th }}$ World Congress on Genetics Applied to Livestock Production (WCGALP).

Allendorf, F.W. and G. Luikart (2007). Conservation and the genetics of populations. Mammalia. 2007: 189-197.

Almathen, F. (2014). Genetic diversity and demographic history of dromedary camel (Camelus dromedarius). Thesis, The University of Nottingham, Nottingham (UK).

Andersson, L. (2001). Genetic dissection of phenotypic diversity in farm animals. Nat. Rev. Genet. 2(2): 130.

Andreas, E., C. Sumantri, H. Nuraini, A. Farajallah and A. Anggraeni (2010). Identification of GH $\mid$ AluI and GHR| AluI genes polymorphisms in Indonesian Buffalo. J. Indones. Trop. Anim. Agric. 35(4): 215-221.
Argetsinger, L.S., G.S. Campbell, X. Yang, B.A. Witthuhn, O. Silvennoinen, J.N. Ihle and C. Carter-Su (1993). Identification of JAK2 as a growth hormone receptor-associated tyrosine kinase. Cell. 74(2): 237-244.

Argetsinger, L.S. and C. Carter-Su (1996). Mechanism of signaling by growth hormone receptor. Physiol. Rev. 76(4): 1089-1107.

Ayuk, J. and M. Sheppard (2006). Growth hormone and its disorders. Postgrad. Med. J. 82(963): 24-30.

Babar, M., T. Hussain, A. Wajid, A. Nawaz, A. Nadeem, S. Shah, M. Shahid, N. Ahmad, K. Javed and M. Abdullah (2015). Mitochondrial cytochrome-b and d-loop sequence based genetic diversity in Mareecha ad Bareela camel breeds of Pakistan. J. Anim. Plant. Sci. 25: 591-594.

Bakheit, S.A., A. Idris, B. Faye and O. Abdelhadi (2012). The effect of management system on camels milk yield and calve growth rate in North Kordofan, Sudan. Tropentag 2012, Göttingen, Germany.

Barash, H., Y. Aharoni, A. Brosh and Z. Holzer (1998). Effects of low energy diets followed by a compensatory diet on body weight gain and plasma hormone concentrations in bull calves. J. Dairy Sci. 81(1): 250-254.

Barendse, W., R. Bunch, M. Thomas, S. Armitage, S. Baud and N. Donaldson (2001). The TG5 DNA marker test for marbling capacity in Australian feedlot cattle. Beef Quality CRC Marbling Symposium. Coffs Harbour, Australia, p52.

Blair, J.C. and M.O. Savage MO (2002). The GH-IGF-I axis in children with idiopathic short stature. Trends Endocrinol. Metab. 13(8): 325-330.

Blanc, C.P. and Y. Ennesser (1989). Approche zoogéographique de la différenciation infraspécifique chez le dromadaire Camelus dromedarius Linné, 1766 (Mammalia: Camelidae). Revue d'Elevage Méd. Vét. Pays Trop. 42(4): 573-587.

Bolormaa, S., J.E. Pryce, A. Reverter, Y. Zhang, W. Barendse, K. Kemper, B. Tier K. Savin, B.J. Hayes and M.E. Goddard (2014). A multi-trait, meta-analysis for detecting pleiotropic polymorphisms for stature, fatness and reproduction in beef cattle. PloS Genetics. 10(3): e1004198.

Buchanan, F., A. Van Kesse, C. Waldner, D. Christensen, B. Laarveld and S. Schmutz (2003). Hot topic: an association between a leptin single nucleotide polymorphism and milk and protein yield. J. Dairy Sci. 86(10): 3164-3166.

Buchanan, F.C., C.J. Fitzsimmon, A.G. Van Kessel, T.D. Thue, D.C. Winkelman-Sim and S.M. Schmutz (2002). Association of a missense mutation in the bovine leptin gene with carcass fat content 
and leptin mRNA levels. Genet. Sel. Evol. 34(1): 105 .

Burger, P.A. 2016. The history of Old World camelids in the light of molecular genetics. Trop. Anim. Health Prod. 48(5): 905-913.

Butler, A.A. and D.L. Roith (2001). Control of growth by the somatropic axis: growth hormone and the insulin-like growth factors have related and independent roles. Ann.l Rev. Physiol. 63(1): 141-164.

Champion, Z., B. Breier, W. Ewen, T. Tobin and P. Casey (2002). Blood plasma concentrations of insulin-like growth factor-I (IGF-I) in resting standardbred horses. Vet. J. 163(1): 45-50.

Charcosset, A. (1997). Marker-assisted introgression of quantitative trait loci. Genetics. 147(3): 14691485.

Charruau, P. (2012). Insights from evolutionary history and population genetics for domestic and wildlife conservation-cases of the Old World camelids and cheetahs. Thesis, University of Veterinary Medicine, Vienna (Austria).

Choudhary, V., P. Kumar, T. Bhattacharya, B. Bhushan, A. Sharma and A. Shukla (2007). DNA polymorphism of insulin-like growth factorbinding protein-3 gene and its association with birth weight and body weight in cattle. J. Anim. Breed. Genet. 124(1): 29-34.

Chuluunbat, B., P. Charruau P, K. Silbermayr, T. Khorloojav and P. Burger P. (2014). Genetic diversity and population structure of Mongolian domestic Bactrian camels (Camelus bactrianus). Anim.Genet. 45(4): 550-558.

Combes, S., I. Louveau, and M. Bonneau (1997). Effect of $\mathrm{GH}$ administration on $\mathrm{GH}$ and IGF-I receptors in porcine skeletal muscle and liver in relation to plasma GH-binding protein. J. Endocrinol. 155(1): 19-26.

Curi, R.A., H. De Oliveira, A.C. Silveira and C. Lopes (2005). Effects of polymorphic microsatellites in the regulatory region of IGF1 and GHR on growth and carcass traits in beef cattle. Anim. Genet. 36(1): 58-62.

Daverio, S., F. Di Rocco and L. Vidal-Rioja (2012). The llama (Lama glama) growth hormone gene: sequence, organization and SNP identification. Small Ruminant Res. 103(2-3): 108-111.

Davis, G. and S. DeNise (1998). The impact of genetic markers on selection. J. Anim. Sci. 76(9): 23312339.

Davoli, R. and S. Braglia (2007). Molecular approaches in pig breeding to improve meat quality. Brief. Funct. Genom. Proteom. 6(4): 313-321.

De la Rosa Reyna, X., H. Montoya, V. Castrellón, A. Rincón, M. Bracamonte and W. Vera (2010). Polymorphisms in the IGF1 gene and their effect on growth traits in Mexican beef cattle. Genet. Mol. Res. 9(2): 875-883.

Di Stasio, L., A. Brugiapaglia, G. Destefanis, A. Albera and S. Sartore S. (2003). GH1 as candidate gene for variability of meat production traits in Piemontese cattle. J. Anim. Breed. Genet. 120(5): 358-361.

Dimitriadis, G., M. Parry-Billings, S. Bevan, D. Dunger, T. Piva, U. Krause, G. Wegener and E. Newsholme (1992). Effects of insulin-like growth factor I on the rates of glucose transport and utilization in rat skeletal muscle in vitro. Biochem. J. 285(1): 269-274.

Dybus, A. and W. Grzesiak (2006). GHRH/HaeIII gene polymorphism and its associations with milk production traits in Polish black-and-white cattle. Arch. Anim. Breed. 49(5): 434-438.

England, P.R., J.-M.Cornuet, P. Berthier, D.A. Tallmon and G. Luikart (2006). Estimating effective population size from linkage disequilibrium: severe bias in small samples. Conserv. Genet. 7(2): 303 .

Etherton, T.D. and D.E. Bauman (1998). Biology of somatotropin in growth and lactation of domestic animals. Physiol. Rev. 78(3): 745-761.

Evan, G.I. and K.H. Vousden (2001). Proliferation, cell cycle and apoptosis in cancer. Nature 411(6835): 342 .

Fan, B., Z.-Q. Du, D.M. Gorbach and M.F. Rothschild (2010). Development and application of highdensity SNP arrays in genomic studies of domestic animals. Asian-Australas. J. Anim. Sci. 23(7): 833-847.

FAOSTAT (2017). Statistical data. Food and Agriculture Organization of the United Nations, Rome.

Fatima, S., S. Bhatt, C. Bhong, D. Rank and C. Joshi (2009). Genetic polymorphism study of IGF-I gene in buffaloes of Gujarat. Buffalo Bull. 28(3): 159-164.

Faye, B. (2015). Role, distribution and perspective of camel breeding in the third millennium economies. Emir. J. Food Agric. 318-327.

Frankham, R. (2005). Genetics and extinction. Biol. Conserv. 126(2): 131-140.

Gao, Y., R. Zhang, X. Hu and N. Li (2007). Application of genomic technologies to the improvement of meat quality of farm animals. Meat Sci. 77(1): 36-45.

Garcia, M., M. Amstalden, S. Williams, R. Stanko, C. Morrison, D. Keisler, S. Nizielski and G. Williams (2002). Serum leptin and its adipose gene expression during pubertal development, the estrous cycle, and different seasons in cattle. J. Anim. Sci. 80(8): 2158-2167.

Ge, W., M. Davis, H. Hines, K. Irvin and R. Simmen (2001). Association of a genetic marker with 
blood serum insulin-like growth factor-I concentration and growth traits in Angus cattle. J. Anim. Sci. 79(7): 1757-1762.

Ge, W., M. Davis, H. Hines, K. Irvin and R. Simmen (2003). Association of single nucleotide polymorphisms in the growth hormone and growth hormone receptor genes with blood serum insulin-like growth factor I concentration and growth traits in Angus cattle. J. Anim. Sci. 81(3): 641-648.

Gordon, D.F., D.P. Quick, C.R. Erwin, J.E. Donelson and R.A. Maurer (1983). Nucleotide sequence of the bovine growth hormone chromosomal gene. Mol. Cell. Endocrinol. 33(1): 81-95.

Government of Pakistan (2008). Economic Survey of Pakistan, 2007-08. Government of Pakistan, Economic Affairs Division, Ministry of Finance Islamabad.

Government of Pakistan (2017). Economic Survey of Pakistan, 2016-17. Government of Pakistan, Economic Affairs Division, Ministry of Finance Islamabad.

Grigson, C. (2012). Camels, copper and donkeys in the early iron age of the southern levant: timna revisited. Levant. 44(1): 82-100.

Grigson, C. (2014). The history of the camel bone dating project. Anthropozoologica 49(2): 225-235.

Guillemin, N., C. Jurie, I. Cassar-Malek, J.-F. Hocquette, G. Renand and B. Picard (2011). Variations in the abundance of 24 protein biomarkers of beef tenderness according to muscle and animal type. Animal 5(6): 885-894.

Hammadi, M., T. Khorchani, G. Khaldi, A. Majdoub, H. Abdouli, N. Slimane, D. Portetelle and R. Renaville (2001). Effect of diet supplementation on growth and reproduction in camels under arid range conditions. Biotechnol. Agron. Soc. Environ. 5(2): 69-72.

Hediger, R., Johnson, S.E., W. Barendse, R.D. Drinkwater, S.S. Moore and J. Hetzel (1990). Assignment of the growth hormone gene locus to $19 \mathrm{q} 26$-qter in cattle and to $11 \mathrm{q} 25$-qter in sheep by in situ hybridization. Genomics $8(1)$ : 171-174.

Hill, W.G. (1981). Estimation of effective population size from data on linkage disequilibrium. Genet. Res. 38(3): 209-216.

Hirschhorn, J.N. and M.J. Daly (2005). Genome-wide association studies for common diseases and complex traits. Nat. Rev. Genet. 6(2): 95.

Hocquette, J., F. Gondret, E. Baéza, F. Médale, C. Jurie and D. Pethick (2010). Intramuscular fat content in meat-producing animals: development, genetic and nutritional control, and identification of putative markers. Animal 4(2): 303-319.
Hradecka, E., J. Citek, L. Panicke, V. Rehout and L. Hanusova (2008). The relation of GH1, GHR and DGAT1 polymorphisms with estimated breeding values for milk production traits of German Holstein sires. Czech J. Anim. Sci. 53(6): 238.

Iqbal, A. (1999). Studies on some of the productive, reproductive and behavioral aspects of camel in Pakistan. PhD thesis, University of Agriculture Faisalabad.

Isani, G. and M. Baloch (2000). Camel breeds of Pakistan. Arab Centre for the Studies of Arid Zones and Dry Lands, Pakistan Ministry of Food, Agriculture and Livestock and and Camel Applied Research and Development Network.

Ishag, I., M. Reissmann, K. Peter, L. Musa and M. Ahmed (2010). Phenotypic and molecular characterization of six Sudanese camel breeds. S. Afr. J. Anim. Sci. 40(4).

Jefferson, L.S., C.M. Schworer and E.L. Tolman (1975). Growth hormone stimulation of amino acid transport and utilization by the perfused rat liver. J. Biol. Chem. 250(1): 197-204.

Ji, R., P. Cui, F. Ding, J. Geng, H. Gao, H. Zhang, J. Yu, S. Hu and H. Meng (2009). Monophyletic origin of domestic bactrian camel (Camelus bactrianus) and its evolutionary relationship with the extant wild camel (Camelus bactrianus ferus). Anim. Genet. 40(4): 377-382.

Jianlin, H., J. Ochieng, B. Lkhagva and O. Hanott (2004). Genetic diversity and relationship of domestic Bactrian camels (Camelus bactrianus) in China and Mongolia. J. Camel Practice Res. 11(2): $97-$ 99.

Kadarmideen, H.N., P. von Rohr and L.L. Janss (2006). From genetical genomics to systems genetics: potential applications in quantitative genomics and animal breeding. Mamm. Genome 17(6): 548-564.

Kadim, I. and O. Mahgoub (2008). Effect of age on quality and composition of one-humped camel Longissimus thoracis muscle. Int. J. Postharvest Technol. Innov. 1(3): 327-336.

Kadwell, M., M. Fernandez, H.F. Stanley, R. Baldi, J.C. Wheeler, R. Rosadio and M.W. Bruford (2001). Genetic analysis reveals the wild ancestors of the llama and the alpaca. Proc. R. Soc. Lond. B. 268(1485): 2575-2584.

Kamoun, M. (1995). Dromedary meat: production, qualitative aspects and acceptability for transformation. Option Mediter. Serie B, Etudes Recherch. 13: 105-130.

Katoh, K., S. Kouno, A. Okazaki, K. Suzuki and Y. Obara (2008). Interaction of GH polymorphism with body weight and endocrine functions in 
Japanese black calves. Domest. Anim. Endocrinol. 34(1): 25-30.

Khan, B., A. Iqbal and M. Riaz (2003). Production and management of Camels, Pakistan. TM Printers, Al-Rahman Plaza, Aminpur Bazar, Faisalabad.

Khatkar, M.S., F.W. Nicholas, A.R. Collins, K.R. Zenger, J.A. Cavanagh, W. Barris, R.D. Schnabel, J.F. Taylor and H.W. Raadsma (2008). Extent of genome-wide linkage disequilibrium in Australian Holstein-Friesian cattle based on a high-density SNP panel. BMC Genomics 9(1): 187.

Kim, J., D. Yoon, B. Park, L. Kim, K. Na, J. Choi, C. Cho, H. Lee, E. Chung and B. Sang (2005). Identification of novel SNPs in bovine insulinlike growth factor binding protein-3 (IGFBP3) gene. Asian-Australas. J. Anim. Sci. 18(1): 3-7.

Kmiec, M., I. Kowalewska-Luczak, H. Kulig and A. Terman (2007). Associations between GHRH/Haelll restriction polymorphism and milk production traits in a herd of dairy cattle. J. Anim. Vet. Adv. 6(11): 1298-1303.

Knight, C.H,, P.A. Fowler and C.J. Wilde (1990). Galactopoietic and mammogenic effects of longterm treatment with bovine growth hormone and thrice daily milking in goats. J. Endocrinol. 127(1): 129-138.

Koopaei, H.K. and A.E. Koshkoiyeh (2011). Application of genomic technologies to the improvement of meat quality in farm animals. Biotechnol. Mol. Biol. Rev. 6(6): 126-132.

Kozhamkulova, B. (1986). The late Cenozoic twohumped (Bactrian) camels of Asia. Quartärpläontolgie (Abh. Ber. Inst. Quartärpläontolgie Weimar). 6: 93-97.

Kurtu, M. (2004). An Assessment of the productivity for meat and the carcase yield of camels (Camelus dromedarius) and of the consumption of camel meat in the eastern region of Ethiopia. Trop. Anim. Health Prod. 36(1): 65-76.

Lewontin, R. and K. Kojima (1960). The evolutionary dynamics of complex polymorphisms. Evolution 14(4): 458-472.

Lincoln, D., F. Sinowatz, E. El-Hifnawi, R. Hughes and M. Waters (1995). Evidence of a direct role for growth hormone $(\mathrm{GH})$ in mammary gland proliferation and lactation. Anat. Histol. Embryol. 24(2): 107-115.

Liu, B. and H. Chen (2006). Research on heterosis and growth performance in Qinchuan Cattle and its hybrids. Chin. J. Anim. Sci. 42(15): 1.

Liu, H.C. and H. Cheng (2002). Integrating molecular approaches with QTL to identify positional candidate genes. In: Proceedings of the 7th World Congress on Genetics Applied to
Livestock Production, Montpellier, France pp. 19-23.

Lord, G.M., G. Matarese, J.K. Howard, R.J. Baker, S.R. Bloom and R.I. Lechler (1998). Leptin modulates the $\mathrm{T}$-cell immune response and reverses starvation-induced immunosuppression. Nature 394(6696): 897.

Louveau, I. and F. Gondret (2004). GH and insulin affect fatty acid synthase activity in isolated porcine adipocytes in culture without any modifications of sterol regulatory element binding protein-1 expression. J. Endocrinol. 181(2): 271-280.

Mackinnon, M. and M. Georges (1998). Marker-assisted preselection of young dairy sires prior to progeny-testing. Livest. Prod. Sci. 54(3): 229250.

Mahmoud, A. (2010). Unravelling the camel's genetic sequence. Nature Publishing Group.

Manefield, G. and A. Tinson (1997). Camels. A compendium Sydney post graduate foundation vade mecum series C no. 22. Sydney: Post Graduate Foundation, Sydney University.

Maniou, Z., O. Wallis, A. Sami and M. Wallis (2001). Molecular evolution of growth hormone in Cetartiodactyla. In: $192^{\text {nd }}$ Meeting of the Society for Endocrinology, 2 BioScientifica.

Maniou, Z., O.C. Wallis and M. Wallis (2004). Episodic molecular evolution of pituitary growth hormone in Cetartiodactyla. J. Mol. Evol. 58(6): 743-753.

Marai, I.F.M., A.E.B. Zeidan, A.M. Abdel-Samee, A. Abizaid and A. Fadiel. (2009). Camels reproductive and physiological performance traits as affected by environmental conditions. Trop. Subttop. Agroecosystems. 10(2): 129-149.

Martin, M.B. and A. Stoica (2002). Insulin-like growth factor-I and estrogen interactions in breast cancer. J. Nutr. 132(12): 3799S-3801S.

Mburu, D., J. Ochieng, S. Kuria, H. Jianlin, B. Kaufmann, J. Rege and O. Hanotte (2003). Genetic diversity and relationships of indigenous Kenyan camel (Camelus dromedarius) populations: implications for their classification. Anim. Genet. 34(1): 26-32.

Mertani, H. and G. Morel (1995). In situ gene expression of growth hormone $(\mathrm{GH})$ receptor and $\mathrm{GH}$ binding protein in adult male rat tissues. Molec. Cell. Endocrinol. 109(1): 47-61.

Meuwissen, T., B. Hayes and M. Goddard (2013). Accelerating improvement of livestock with genomic selection. Annu. Rev. Anim. Biosci. 1(1): 221-237.

Meuwissen. T.H., B.J. Hayes and M.E. Goddard (2001). Prediction of total genetic value using genomewide dense marker maps. Genetics 157: 18191829. 
Michal, J., Z. Zhang, C. Gaskins and Z. Jiang (2006). The bovine fatty acid binding protein 4 gene is significantly associated with marbling and subcutaneous fat depth in Wagyu x Limousin F2 crosses. Anim. Genet. 37(4): 400-402.

Miller, P., B. Rei., C. Calvert, E. DePeters and R. Baldwin (1991). Relationship of early lactation and bovine somatotropin on nutrient uptake by cow mammary glands. J. Dairy Sci. 74(11): 3800-3806.

Mullen, A., P. Stapleton, D. Corcoran, R. Hamill and A. White (2006). Understanding meat quality through the application of genomic and proteomic approaches. Meat Sci. 74(1): 3-16.

Mullen, M.P., D.P. Berry, D.J. Howard, M.G. Diskin, C.O. Lynch, L. Giblin, D.A. Kenny, D.A. Magee, K.G. Meade and S.M. Waters (2011). Single nucleotide polymorphisms in the insulinlike growth factor 1 (IGF-1) gene are associated with performance in Holstein-Friesian dairy cattle. Front. Genet. 2: 3.

Nielsen, M. and K. Jakobsen (1993). Changes in mammary glucose and protein uptake in relation to milk synthesis during lactation in high-and low-yielding goats. Comp Biochem Physiol Comp Physiol. 106(2): 359-365.

Nkrumah, J., C. Li, J. Basarab, S. Guercio, Y. Meng, B. Murdoch, C. Hansen and S. Moore (2004). Association of a single nucleotide polymorphism in the bovine leptin gene with feed intake, feed efficiency, growth, feeding behaviour, carcass quality and body composition. Can. J. Anim. Sci. 84(2): 211-219.

Noble, G., E. Houghton, C. Roberts, J. Faustino-Kemp, S. De Kock, B. Swanepoel and M. Sillence (2007). Effect of exercise, training, circadian rhythm, age, and sex on insulin-like growth factor-1 in the horse. J. Anim. Sci. 85(1): 163171.

Oprządek, J. and K. Flisikowski (2003). Polymorphisms at loci of leptin (LEP), Pit1 and STAT5A and their association with growth, feed conversion. Anim. Sci. Pap. Rep. 21(3): 135-145.

Ovenden, J.R., D. Peel, R. Street, A,J. Courtney, S.D. Hoyle, S.L. Peel and H. Podlich (2007). The genetic effective and adult census size of an Australian population of tiger prawns (Penaeus esculentus). Mol. Ecol. 16(1): 127-138.

Ozawa, A., H. Inokuma and T. Johke (1995). The relationship between plasma insulin-like growth factor-I (IGF-I) level and body weight in the horse. J. Vet. Med. Sci. 57(6): 1105-1107.

Page. B., E. Casas, R. Quaas, R. Thallman, T. Wheeler, S. Shackelford, M. Koohmaraie, S. White, G. Bennett and J. Keele (2004). Association of markers in the bovine CAPN1 gene with meat tenderness in large crossbred populations that sample influential industry sires. J. Anim. Sci. 82(12): 3474-3481.

Pérez, P., M. Maino, R. Guzmán, A. Vaquero, C. Köbrich and J. Pokniak (2000). Carcass characteristics of llamas (Lama glama) reared in Central Chile. Small Ruminant Res. 37(1-2): 93-97.

Plaut, K., R.L. Maple, C.E. Wade, L.A. Baer, and A.E. Ronca (2003). Effects of hypergravity on mammary metabolic function: gravity acts as a continuum. J. Appl. Physiol. 95(6): 2350-2354.

Qiu B, Liu J, Liu Z and Liu S. 2002. Distribution and ecology of the edible cyanobacterium Ge-XianMi (Nostoc) in rice fields of Hefeng County in China. J. Appl. Phycol. 14(5): 423-429.

Qureshi, M., G. Khan and S. Yaqoob (1993). Textbook of forestry and range management. Kazi, Lahore.

Rahbar, R., G. Rahimi, Z.A. Pirsaraei and M. Gholizadeh (2010). Identification of polymorphism in promoter region of growth hormone receptor (GHR) gene and its association with milk related traits in Holstein cows. Afr. J. Biotechnol. 9(33).

Raziq, A. (2009). Portrayal of Camelids in pastoral economy of northeastern herders of Balochistan. $\mathrm{PhD}$ thesis, University of Agriculture, Faisalabad.

Rhoads, M., J. Meyer, W. Lamberson, D. Keisler and M. Lucy (2008). Uterine and hepatic gene expression in relation to days postpartum, estrus, and pregnancy in postpartum dairy cows. J. Dairy Sci. 91(1): 140-150.

Rinderknecht, E. and R.E. Humbel (1978). The amino acid sequence of human insulin-like growth factor I and its structural homology with proinsulin. J. Biol. Chem. 253(8): 2769-2776.

Ropp, J., R. Raub and J. Minton (2003). The effect of dietary energy source on serum concentration of insulin-like growth factor-I, growth hormone, insulin, glucose, and fat metabolites in weanling horses. J. Anim. Sci. 81(6): 1581-1589.

Rotwein, P. (2017). Diversification of the insulin-like growth factor 1 gene in mammals. PloS One 12(12): e0189642.

Rotwein, P., A.M. Gronowski and M.J. Thomas (1994). Rapid nuclear actions of growth hormone. Horm. Res. Paediatr. 42(4-5): 170-175.

Sabahat S., A. Nadeem, M. Javed, M.Y. Zahoor, S. Nabeel and A.S. Hashmi (2020). Amino acid substitutions in growth hormone and growth hormone receptor genes mutants in Camelus dromedarius. Pakistan J. Zool. 52(1): 49-54.

Sabahat, S., A. Nadeem, M. Javed, M.Y. Zahoor, A.S. Hashmi, G. Yasein and G. Abbas (2020a). Genetic polymorphisms of IGF-1 gene in Pakistani Marecha camel. Pakistan J. Zool, 52(1):1-4. 
Sabahat S., M.S. Khatkar, A. Nadeem and P.C. Thomson (2020b). Analysis of variation in growth and spline-based growth models for Marecha and Lassi dromedary camels. Trop. Anim. Health Prod. Online early: https://doi.org/10.1007/s11250-020-02250-5.

Sakandar, H.A., S. Ahmad, R. Perveen, H.K.W. Aslam, A. Shakeel, F.A. Sadiq and M. Imran (2018). Camel milk and its allied health claims: a review. Prog. Nutr. 20(1-S): 15-29.

Sañudo, C., B. Panea, J. Olleta, F. Mansón, I. Sierra, P. Alberti, P. Ertbjerg, M. Christiansen, S. Gigli and S. Failla (2004). Carcass quality of several European cattle breeds: preliminary results. In: $50^{\text {th }}$ International Congress of Meat Science and Technology.

Saparov, G. and O. Annageldiyev (2005). Meat productivity of the camel Arvana breed and ways to increase it. In: Desertification Combat and Food Safety. 211-214.

Schlee, P., R. Graml, E. Schallenberger, D. Schams, O. Rottmann, A. Olbrich-Bludau and F. Pirchner (1994). Growth hormone and insulin-like growth factor I concentrations in bulls of various growth hormone genotypes. Theor. Appl. Genet. 88(34): 497-500.

Schuller, A., E. Zwarthoff and S. Drop (1993). Gene expression of the six insulin-like growth factor binding proteins in the mouse conceptus during mid-and late gestation. Endocrinol. 132(6): 2544-2550.

Schulz, U., I. Tupac-Yupanqui, A. Martínez, S. Méndez, J.V. Delgado, M. Gómez, S. Dunner and J. Cañón (2010). The Canarian camel: a traditional dromedary population. Diversity 2(4): 561-571.

Schwartz, M.K., D.A.Tallmon and G. Luikart (1998). Review of DNA-based census and effective population size estimators. In: Animal Conservation Forum, 1 pp. 293-299. Cambridge University Press.

Shah, M., A. Qureshi, M. Reissmann and H. Schwartz (2006). Sequencing and sequence analysis of myostatin gene in the exon 1 of the camel (Camelus dromedarius). Pakistan Vet. J. 26(4): 176.

Shengli, L.. (2009). Overview on the production state of young white beef at home and abroad. J. Dairy Sci. Technol. 5: 003.

Sherman, E., J. Nkrumah, C. Li, R. Bartusiak, B. Murdoch and S. Moore (2009). Fine mapping quantitative trait loci for feed intake and feed efficiency in beef cattle. J. Anim. Sci. 87(1): 3745 .

Siadkowska, E., L. Zwierzchowski, J. Oprzadek, N. Strzalkowska, E. Bagnicka and J. Krzyzewski (2006). Effect of polymorphism in IGF-1 gene on production traits in Polish Holstein-Friesian cattle. Anim. Sci. Pap. Rep. 24(3): 225-237.

Silbermayr, K., P. Orozco-terWengel, P. Charruau, D. Enkhbileg, C. Walzer, C. Vogl, F. Schwarzenberger, P. Kaczensky and P. Burger (2010). High mitochondrial differentiation levels between wild and domestic Bactrian camels: a basis for rapid detection of maternal hybridization. Anim. Genet. 41(3): 315-318.

Sinowatz, F., S. Kölle, D. Schams and A. Plath (2002). Expression and localization of growth factors during mammary gland development. In: Biology of the Mammary Gland pp. 19-25. Springer.

Slatkin, M. (2008). Linkage disequilibriumunderstanding the evolutionary past and mapping the medical future. Nat. Rev. Genet. 9(6): 477.

Soltanizadeh, N., M. Kadivar, J. Keramat, H. Bahrami and F. Poorreza (2010). Camel cocktail sausage and its physicochemical and sensory quality. Int. J. Food Sci. Nutr. 61(2): 226-243.

Sorbolini, S., G. Marras, G. Gaspa, C. Dimauro, M. Cellesi, A. Valentini and N.P. Macciotta (2015). Detection of selection signatures in Piemontese and Marchigiana cattle, two breeds with similar production aptitudes but different selection histories. Genet. Sel. Evol. 47(1): 52.

Stanley. H.F., M. Kadwell and J.C. Wheeler (1994). Molecular evolution of the family Camelidae: a mitochondrial DNA study. Proc. R. Soc. Lond. B. 256(1345): 1-6.

Sundström, M., T. Lundqvist, J. Rödin, L.B. Giebeli, D. Milligani and G. Norstedt (1996). Crystal structure of an antagonist mutant of human growth hormone, G120R, in complex with its receptor at 2.9 Angstrom resolution. J. Biol. Chem. 271(50): 32197-32203.

Sumantran. V., M. Tsai and J. Schwartz (1992). Growth hormone induces c-fos and c-jun expression in cells with varying requirements for differentiation. Endocrinol. 130(4): 2016-2024.

Suravajhala, P., L.J. Kogelman and H.N. Kadarmideen (2016). Multi-omic data integration and analysis using systems genomics approaches: methods and applications in animal production, health and welfare. Genet. Sel. Evol. 48(1): 38.

Tallmon, D.A., A. Koyuk, G. Luikar and M.A. Beaumont (2008). Computer programs: onesamp: a program to estimate effective population size using approximate Bayesian computation. Mol. Ecol. Resour. 8(2): 299-301.

Tandon, S., U. Bissa and N. Khanna (1988). Camel meat: present status and future prospects. Ann. Arid Zone. 27(1): 23-28. 
Thomas, M., R. Enns, K. Shirley, M. Garcia, A. Garrett and G. Silver (2007). Associations of DNA polymorphisms in growth hormone and its transcriptional regulators with growth and carcass traits in two populations of Brangus bulls. Genet. Mol. Res. 6(1): 222-237.

Tixier-Boichard, M. (2002). From phenotype to genotype: major genes in chickens. Worlds Poult. Sci. J. 58(1): 65-75.

Uerpmann, H.-P. and M. Uerpmann (2002). The appearance of the domestic camel in south-east Arabia. J. Oman. Stud. 12: 235-260.

Uerpmann, M/ and H.-P. Uerpmann (2012). IVDromedaries (Camelus dromedarius): Archeozoology of camels in south-eastern Arabia. Verlag der Österreichischen Akademie der Wissenschaften.

Vijh, R., M.S. Tantia, B. Mishra and S.T. Bharani Kumar (2007). Genetic diversity and differentiation of dromedarian camel of India. Anim. Biotechnol. 18(2): 81-90.

Von den Driesch, A. and H. Obermaier (2007). The hunt for wild dromedaries during the 3rd and 2nd millennia $\mathrm{BC}$ on the United Arab Emirates coast. Camel bone finds from the excavations at Al Sufouh 2 Dubai, UAE. Skeletal Series and Their Socio-Economic Context, Documenta Archaeolbiologiae. 133-167.

Wang, Z., G. Ding, G. Chen, Y. Sun, Z. Sun, H. Zhang, L. Wang, S. Hasi, Y. Zhang and J. Li (2012). Genome sequences of wild and domestic bactrian camels. Nat. Commun. 3: 1202-1202.

Waples, R.S. (2006). A bias correction for estimates of effective population size based on linkage disequilibrium at unlinked gene loci. Conserv. Genet. 7(2): 167.
Waritthitham, A., C. Lambertz, H.-J. Langholz, M. Wicke and M, Gauly (2010). Assessment of beef production from Brahman $\times$ Thai native and Charolais $\times$ Thai native crossbred bulls slaughtered at different weights. II: Meat quality. Meat Sci. 85(1): 196-200.

Wood, D., W. Salsgiver, T. Kasser, G. Lange, E. Rowold, B. Violand, A. Johnson, R. Leimgruber, G. Parr and N. Siege (1989). Purification and characterization of pituitary bovine somatotropin. J. Biol. Chem. 264(25): 1474114747.

Woods, S.C., R.J. Seeley, D. Porte and M.W. Schwartz (1998). Signals that regulate food intake and energy homeostasis. Science. 280(5368): 13781383.

Wu, H., X. Guang, M.B. Al-Fageeh, J. Cao, S. Pan, H. Zhou, L. Zhang, M.H. Abutarboush, Y. Xing and Z. Xie (2014). Camelid genomes reveal evolution and adaptation to desert environments. Nat. Ccommun. 5: 5188.

Xie, X, Q. Meng, Z. Cui and L. Ren (2012). Effect of cattle breed on meat quality, muscle fiber characteristics, lipid oxidation and fatty acids in China. Asian-Australas. J. Anim. Sci. 25(6): 824.

Yahyaoui, M.H., A. Coll, A. Sanchez and J.M. Folch (2001). Genetic polymorphism of the caprine kappa casein gene. J. Dairy Res. 68(2): 209-216.

Yee, D. (1994). The insulin-like growth factor system as a target in breast cancer. Breast Cancer Res. Treat. 32(1): 85-95.

Zhou, Y. (2007).. Effects of growth hormone and insulinlike growth factor-I on milk protein gene expression and nutrient uptake and cell proliferation in clonal bovine mammary epithelial cells. $\mathrm{PhD}$ thesis, Virginia Tech. 